\title{
Alpha Mangostin and Xanthone Activity on Fasting Blood Glucose, Insulin and Langerhans Islet of Langerhans in Alloxan Induced Diabetic Mice
}

\author{
Welly Ratwita ${ }^{1, *}$, Elin Yulinah Sukandar ${ }^{2}$, I Ketut Adnyana², Neng Fisheri Kurniati²
}

\section{Welly Ratwita ${ }^{1, *}$ \\ Elin Yulinah Sukandar ${ }^{2}$ \\ I Ketut Adnyana² Neng Fisheri Kurniati ${ }^{2}$ \\ 'Department of Pharmacology, Jen- deral Achmad Yani University, Bandung Institute of Technology, Jawa Barat, INDONESIA. \\ ${ }^{2}$ Department of Pharmacology and Clinical Pharmacy, Bandung Institute of Technology, Jawa Barat, INDONESIA.}

\section{Correspondence}

Mrs. Welly Ratwita

Department of Pharmacology, Jenderal Achmad Yani University-Department of Pharmacology and Clinical Pharmacy, School of Pharmacy, Bandung Institute of Technology, Jawa Barat, INDONESIA.

Phone no: +62-82117811700

Email: wellyratwita@gmail.com

$$
\begin{aligned}
& \text { History } \\
& \text { - Submission Date: 07-04-2018; } \\
& \text { - Review completed: 23-05-2018; } \\
& \text { - Accepted Date: 05-07-2018. }
\end{aligned}
$$

DOI : 10.5530/pj.2019.1.12

Article Available online http://www.phcogj.com/v11/i1

\section{Copyright}

C 2019 Phcog.Net. This is an open-access article distributed under the terms of the Creative Commons Attribution 4.0 International license.

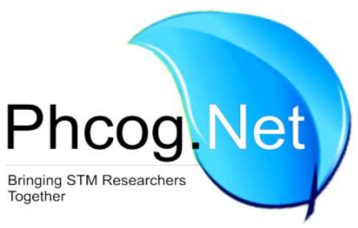

\begin{abstract}
Objective: This research elaborated role of alpha mangostin and xanthone on fasting blood glucose, insulin and langerhans islet in alloxan induced diabetic mice. Methods: Fasting blood glucose, insulin and langerhans islet test were conducted using male Mus musculus mice, divided into 10 groups randomly, which were normal, control (alloxan induced only), glibenclamide, various doses of $\alpha$-mangostin and xanthone $(5,10,20 \mathrm{mg} / \mathrm{kgbw})$. Mice were treated for 21 days. Overnight-fasted mice (12 h) were sacrificed by cervical decapitation on day $21^{\text {st }}$, following the ethical norms granted by the ethics committee. Fasting blood glucose and insulin plasma were checked. Pancreatic tissues were excised from sacrificed animals, and then fixed in $10 \%(\mathrm{v} / \mathrm{v})$ neutral buffered formalin. Histologic observations for Langerhans area were performed after staining using Gomori staining method. Results: The effects of alpha mangostin and xanthone on fasting blood glucose different significantly to control, and were not significantly different from glibenclamide and metformin. Increasing alpha mangostin/xanthone dose from $5 \mathrm{mg} / \mathrm{kgbw}$ to $20 \mathrm{mg} / \mathrm{bw}$ also did not cause significant differences, although the best results were obtained at a dose of $20 \mathrm{mg} / \mathrm{kgbw}$. Insulin plasma analize showed that there were no significant difference between alpha mangostin/xanthone to normal group, except xanthone $10 \mathrm{mg} / \mathrm{kgbw}$. Langerhans area showed significant difference between alpha mangostin/xanthone to control group. But there's still had significant difference if we compare to glibenclamid/metformin group. Conclusion: Alpha mangostin and xanthone are two substances that showed antidiabetic effect on fasting blood glucose level, insulin plasma and Langerhans islet.

Key words: $\alpha$-mangostin, Xanthone, Fasting blood glucose, Insulin plasma, Langerhans.
\end{abstract}

\section{INTRODUCTION}

Diabetes mellitus is a metabolic disorder characterized by derangement in carbohydrate, fat and protein metabolisms resulting from impairment in glucose homeostasis, lack of insulin secretion, and development of macro-and microvascular dysfunctions. ${ }^{1}$ Modern antidiabetic agents like sulphonylureas, thiazolidinediones, and biguanides are commercially prescribed but failed to provide a prolonged glycaemic control effect. ${ }^{2}$ The prevalence of diabetes mellitus (DM) risen dramatically in worldwide. ${ }^{1} \mathrm{DM}$ will affect 438 million people by 2030 , with $70 \%$ of cases occur in low-middle income countries. Without proper treatments, DM may cause cardiovascular disease as the major cause of morbidity and mortality. ${ }^{3-4}$ During the development of Type- 2 diabetes, insulin's ability to stimulate the cellular uptake of glucose from the blood was impaired. ${ }^{5-6}$

Hyperglycemia in diabetes mellitus can cause autooxidation of glucose, protein glycation and polyol pathway activation metabolism, thus increasing the formation of reactive oxygen species (ROS). Excessive ROS production will lead to oxidative stress. Oxidative stress was ROS production exceeds the antioxidant capacity. ${ }^{7-8}$

Prolonged elevation of blood glucose concentration as in poorly controlled diabetes, may cause blindness, renal failure, cardiac and peripheral vascular disease, and also neuropathy. Therefore, blood glucose concentrations need to be maintained within narrow limits. This indication marks the increased levels of oxidative stress in diabetic. Oxidative stress is strongly associated with pathogenesis of diabetes, therefore, it can be postulated that the antioxidants may exert a key role in the management of DM. . $^{7-8}$

Hyperglycemia after meal rapidly stimulates insulin secretion, within minute in increased glucose transport, metabolism, and storage by muscle and adipocytes. Insulin stimulates GLUT-4 translocation by 
initiating insulin binding to receptors on the plasma membrane. This bond will activate tyrosine phosphorylation of the receptor intracellular kinase. Stimulation of glucose transport in muscle cells and adipocytes need the phosphoinositide-3 kinase. Phosphoinositide-3 kinase will activate the protein kinase B (serine-threonine kinase). Stimulation of glucose transport in diabetic subjects impaired by the change of insulin levels, while activation of protein kinase remained normal. ${ }^{6-9}$ Alpha mangostin and xanthone effect on glucose transporter were reported in previous publication. The main goal of diabetes treatment is to keep blood sugar levels within a normal range. Hypoglycemic drugs can restore blood sugar levels within the normal range. ${ }^{6}$ Xanthone is a bioactive compounds belongs to mangosteen rind that were thought to have antidiabetic effect which can lower blood sugar levels in patients with diabetes mellitus. Alpha mangostin is one of xanthone active compound. ${ }^{10}$

Medicinal plants have been widely used to treat diabetes due to their safety, effectiveness, affordability, and acceptability. Garcinia mangostana Linn., generally known as mangosteen and belongs to the family Clusiaceae, is a tree cultivated for centuries in the tropical rainforest ${ }^{11}$ Phytochemical studies of G. mangostana extracts report that this plant contains a variety of secondary metabolites such as oxygenated and prenylated xanthones. ${ }^{12}$ Moreover, 50 xanthones have been identified in G. mangostana. ${ }^{13}$

Provided the $\beta$-cells are fully functional, sulphonylureas such as glibenclamide may cause hypoglycemia because insulin release is initiated even when glucose concentrations are below the normal threshold for glucose-stimulated insulin release (approximately $5 \mathrm{mmol} / \mathrm{L}$ or $90 \mathrm{mg} /$ $\mathrm{dL})^{2}$ This was indicate their potentiation on insulin secretion and the enhanced peripheral utilization of insulin in diabetic mice, as supported by the hystopathological findings.

\section{MATERIALS AND METHODS}

\section{Drugs, chemicals, and reagents}

The drugs used in the present study were glibenclamide, metformin, alpha mangostin, xanthone and alloxan monohydrate (Sigma-Aldrich, St. Louis, MO, USA), while the chemicals used were ethanol, chloroform, diethyl ether, formaldehyde, and paraffin wax (Merck, Germany). All chemicals and reagents used were of analytical grade.

Healthy adult male Mus musculus mice (weighted 20-25 g; aged 10-12 weeks), of Department of Biology, School of Life Science, Bandung Institute of Technology. They were housed under standard laboratory conditions. Upon arrival, the animals were left to be acclimatized for a week under laboratory conditions in the animal laboratory, Faculty of Pharmacy, ITB, Indonesia. The mice were randomly assigned to 9 equal groups $(n=5)$ and housed separately in polypropylene cages.

The animals were kept under standard environmental conditions (temperature $25 \pm 2^{\circ} \mathrm{C}$, relative humidity $55 \pm 10 \%$, and $12 \mathrm{~h} \mathrm{light/dark} \mathrm{cycle)}$ and were maintained under standard pellet diet and water ad-libitum. All experiments were performed in accordance with the current ethical norms approved by the Ethical approval was obtained from the research ethic commission team of Hasan Sadikin Hospital Bandung No.1148/ UN6.C1.3.2/ KEPK/PN/2016

\section{Experimental Design}

Hypoglycemic activity of alpha mangostin and xanthone was assessed in the normal and alloxan-induced diabetic mice. Glibenclamide (0.65 $\mathrm{mg} / \mathrm{kgbw}$ ) was used as a reference drug (control positive group) during the study. All the test samples were administered through oral route. The mice were randomly assigned into 10 groups of five animals each. The blood concentration of glucose in normal mice should be within $80-110$ $\mathrm{mg} / \mathrm{dl}$. Diabetic mice were confirmed three days after single alloxan (70 $\mathrm{mg} / \mathrm{kgbw}$, i.v.) injection that freshly dissolved in $0.9 \%$ saline. Control mice were injected with only $0.9 \%$ saline without following treatment. The test animals in $2^{\text {nd }}$ groups to $9^{\text {th }}$ will became diabetic within $72 \mathrm{~h}$ after alloxan administration. The diabetic state was confirmed by measuring basal blood glucose concentration $72 \mathrm{~h}$ after alloxan injection.

Alloxan has two different effect, it selectively inhibits glucose-induced insulin secretion through specific inhibition of glucokinase and it caused a state of insulin-dependent diabetes mellitus through its ability to induce ROS formation, resulting in selective necrosis of beta cells. ${ }^{14}$ Alloxan were toxic to pancreatic beta cells, insulin granule secretion in pancreatic beta decreases.

All animals were kept and maintained under laboratory conditions and were got free access to food (standard pellet diet) and water. Before the commencement of our experiments, the normal group, and also alloxantreated diabetic mice were fasted for $12 \mathrm{~h}$, but still allowed free access to water. At the end of the $12 \mathrm{~h}$ fasting period, blood glucose levels of the fasted normal and alloxan treated mice were determined and recorded. Fasted alloxan-treated mice with blood glucose consentration $250 \mathrm{mg} /$ dl. were considered to be diabetic, and were included in the experiments. A blood sample was obtained from the tail vein of the animals and their fasting blood glucose levels were determined using a digital glucometer (Accu-chek).

The treatment commenced 3 days after the alloxan monohydrate injection, which was considered as day 1 of treatment, and continued for another 21 days. Group 1 served as the normal control and received only vehicle, while Group 2 served as the positive control group, which was diabetic and received vehicle only. On the other hand, group 3, 4, and 5, diabetic mice, were orally administered with alpha mangostin at the dose of 5, 10 or $20 \mathrm{mg} / \mathrm{bw}$, respectively. Group 5, 6, and 7 diabetic mice were orally administered with xanthone at the dose of 5,10 or $20 \mathrm{mg} / \mathrm{kgbw}$, respectively. Group 9 received $0.65 \mathrm{mg} / \mathrm{kgbw}$ glibenclamide. Group 9 received $65 \mathrm{mg} / \mathrm{kgbw}$ metformin. All treatment were given for 21 days. At the last day, the mice were fasted for $12 \mathrm{~h}$, but allowed a free access to water. At the end of fasting period, blood glucose level was measured by tail vein puncture.

\section{Insulin Plasma}

Overnight-fasted mice ( $12 \mathrm{~h}$ ) were sacrificed by cervical decapitation on Day 21 of the experiments following the ethical norms granted by the ethics committee. The blood was collected in serum separation tubes (BD Vacationer ${ }^{\circledR}$ SST II). Samples used in this test were the plasma obtained from the experimental animals that were also used in the fasting blood glucose test above. The blood was centrifuged at 10,000 rpm for $15 \mathrm{~min}$, and tested using an elisa mouse insulin kit (Elabscience-EEl-M2614). The sample/standard solution used for each well was $100 \mu$, then incubated for $90 \mathrm{~min}$ at $37^{\circ} \mathrm{C}$. After incubation, the remaining liquid was removed, then $100 \mu$ biotinylated detection antibody was added, incubated for $1 \mathrm{~h}$ at $37^{\circ} \mathrm{C}$. Perform aspiration and wash buffer for 5 times. Added $90 \mu \mathrm{l}$ substrate reagent, incubated for $15 \mathrm{~min}$ at $37^{\circ} \mathrm{C}$. Added $50 \mu \mathrm{l}$ stop solution and read using elisa reader at $450 \mathrm{~nm}$ wavelength.

\section{Histological Procedures}

Pancreatic tissues were excised from sacrificed animals, and then fixed in $10 \%(\mathrm{v} / \mathrm{v})$ neutral buffered formalin. The fixed tissues or organs were then dehydrated and embedded in paraffin wax before being sectioned to approximately $5 \mu \mathrm{m}$ thickness. Histologic observations for Langerhans islet were performed after staining by Gomori staining method. The slides were examined using light microscope at a magnification power of $400 x$. 


\section{Embedding Pancreas}

The first step embedding (planting) is the pancreas organ immersed in a fixative solution. Then, it was soaked in $70 \%$ ethanol for $24 \mathrm{~h}$, then transferred and immersed in $80 \%$ ethanol for $2 \mathrm{~h}$; ethanol $90 \%$ for 20 $\mathrm{min}$; $95 \%$ ethanol for $20 \mathrm{~min}$, and absolute ethanol for $20 \mathrm{~min}$. Each step is repeated for 3 times. The next treatment is removal of the pancreas organ in xylol solution 1 and 2 respectively for $20 \mathrm{~min}$ and the $3^{\text {rd }}$ at a temperature of $60-63^{\circ} \mathrm{C}$ for $30 \mathrm{~min}$. Further, organ pancreas dipped in liquid paraffin was poured into the container. After a while paraffin would solidify and pancreas was put in a paraffin block.

\section{Making Preparations Pancreas}

The first step was to enter the pancreas in paraffin blocks before embedding the clip results (block holder) microtome and arranged parallel to the blade microtome. The pancreas was cut to a size of $5 \mu \mathrm{m}$. Sliced drawn with a brush and put water at room temperature to unfold that may occur in preparations. Results slices removed with a brush in warm water $38-40^{\circ} \mathrm{C}$ for rectifying existing wrinkles. Slices were stretched perfectly taken with a glass object. Selected pieces were dried and placed on a hot plate at $38-40^{\circ} \mathrm{C}$ until further dried and the preparations stored in an incubator at a temperature of $38-40^{\circ} \mathrm{C}$ for $24 \mathrm{~h}$.

\section{Gomori's Staining}

Staining begins with deparafinisasi phase. Deparafinisasi phase was the preparations included in the multilevel $1^{\text {st }} 3^{\text {rd }}$ xylol respectively for 5 min. Furthermore, stage of rehydration preparations included in the ethanol-rise started from absolute $1^{\text {st }}-3^{\text {rd }}$ ethanol, ethanol $95 \%, 90 \%, 80 \%$, and $70 \%$ respectively for $5 \mathrm{~min}$.

Deparaffinized sections was bring to water. Oxidize in a mixture of equal part of $0.5 \%$ potassium permanganate and $0.5 \%$ sulfuric acid for $2 \mathrm{~min}$, then rinse in distilled water. After decolorized in $2 \%$ sodium bisulphite, washed under tap for $2 \mathrm{~min}$. Stained in Gomori's aldehyde-fuchsin for $2 \mathrm{~min}$. The next stage is to include preparations dehydration in graded ethanol series of $80 \%, 90 \%$, and $95 \%$ to absolute ethanol 1-3. Further clearing is done by inserting xylol preparations at 1, 2, and dried. Further mounting (adhesion) with entellan and ready observed under light microscope with a magnification of 400 times.

\section{RESULTS AND DISCUSSION}

Adapted mice was determined for fasting blood glucose levels initially to obtain a homogeneous sample. Then all animal groups were induced to be diabetic models with alloxan induction of $70 \mathrm{mg} / \mathrm{kgbw}$ intravenously, except the normal group. The development of hyperglycemia is then examined after $72 \mathrm{~h}$ with regular feeding and drinking as usual. On the third day, a blood glucose (FBG1) test was performed. On the $21^{\text {st }}$ day, fasting blood glucose levels were checked again (FBG21).

Based on the above Table 1 , it can be seen that until $21^{\text {st }}$ day after administration of alpha mangostin and glibenclamide, there was a significant decrease in fasting blood glucose, when compared with positive control. The effects of alpha mangostin are not significantly different from the effects of glibenclamide. Increasing doses of alpha mangostin from $5 \mathrm{mg} /$ $\mathrm{kgbw}$ to $20 \mathrm{mg} / \mathrm{kgbw}$ also did not cause significant differences, although the best results were obtained at a dose of $20 \mathrm{mg} / \mathrm{kgbw}$. Presumably this is caused by its effect on increasing insulin secretion.

\section{Insulin Plasma}

The insulin plasma measured in this study came from the same experimental animal as the fasting blood glucose measured above. In contrast
Table 1: Fasting blood glucose level (mg/dl) after 21 days treatment on diabetic animal model, induced by alloxan.

\begin{tabular}{cccc}
\hline Group & FBG1 \pm SD & FBG21 \pm SD & D FBG1-21 \pm SD \\
\hline Normal & $115.40 \pm 9.63$ & $117.80 \pm 5.63$ & $-2.40 \pm 7.70^{\mathrm{a}}$ \\
Control & $411.60 \pm 57.79$ & $491.60 \pm 48.26$ & $-80 \pm 23.15$ \\
AM $5 \mathrm{mg} / \mathrm{kgbw}$ & $484.00 \pm 50.49$ & $311.40 \pm 74.36$ & $172,60 \pm 79.20^{\mathrm{a}}$ \\
$\mathrm{AM} 10 \mathrm{mg} / \mathrm{kgbw}$ & $516.40 \pm 19.27$ & $338.00 \pm 60.52$ & $178.40 \pm 51.50^{\mathrm{a}}$ \\
$\mathrm{AM} 20 \mathrm{mg} / \mathrm{kgbw}$ & $467.60 \pm 76.87$ & $260.40 \pm 65.92$ & $207.20 \pm 46.01^{\mathrm{a}}$ \\
Xa $5 \mathrm{mg} / \mathrm{kgbw}$ & $494.40 \pm 69.18$ & $353.60 \pm 115.54$ & $140.80 \pm 54.80^{\mathrm{a}}$ \\
Xa $10 \mathrm{mg} / \mathrm{kgbw}$ & $508.80 \pm 57.84$ & $349.80 \pm 138.56$ & $159.00 \pm 88.37^{\mathrm{a}}$ \\
Xa $20 \mathrm{mg} / \mathrm{kgbw}$ & $488.40 \pm 88.50$ & $311.20 \pm 99.30$ & $177.20 \pm 96.54^{\mathrm{a}}$ \\
Glib 0.65 mg/kgbw & $495.00 \pm 84.77$ & $284.80 \pm 102.06$ & $210.20 \pm 124.14^{\mathrm{a}}$ \\
Met $65 \mathrm{mg} / \mathrm{kgbw}$ & $489.00 \pm 26.13$ & $296.80 \pm 94.65$ & $192.20 \pm 76.98^{\mathrm{a}}$ \\
\hline
\end{tabular}

Note: AM: Alpha mangostin; Xa: Xanthone; FBG1: Fasting blood glucose level 72 hs after $70 \mathrm{mg} / \mathrm{bw}$ intravenous alloxan injection; FBG21: Fasting blood glucose level 21 days after treatment; D FBG1-21: difference between fasting blood glucose level before and after treatment ; a: $p<0,05$ anova test, mean of fasting blood glucose level between tretment group compared to control

to fasting blood glucose, plasma insulin was measured only at the end of the study.

Based on the above Table 2, there was a significant increase in plasma insulin, between group that received glibenclamide, alpha mangostin $20 \mathrm{mg} / \mathrm{bw}$ when compared with control on the $21^{\text {st }}$ day after treatment. While there's no significant difference between alpha mangostin $20 \mathrm{mg} /$ bw, glibenclamide and normal group. We can conclude that alpha mangostin $20 \mathrm{mg} / \mathrm{bw}$ effect on insulin plasma equal with glibenclamide.

Table 2: Insulin Plasma (ng/dl) on diabetic animal model induced by alloxan.

\begin{tabular}{cc}
\hline Group & Insulin plasma \pm SD $(\mathrm{ng} / \mathrm{ml})$ \\
\hline Normal & $0.280 \pm 0.09^{\mathrm{a}}$ \\
Control & $0.172 \pm 0.06$ \\
$\mathrm{AM} 5 \mathrm{mg} / \mathrm{kgbb}$ & $0.244 \pm 0.48$ \\
$\mathrm{AM} 10 \mathrm{mg} / \mathrm{kgbb}$ & $0.265 \pm 0.07$ \\
$\mathrm{AM} 20 \mathrm{mg} / \mathrm{kgbb}$ & $0.285 \pm 0.04^{\mathrm{a}}$ \\
Xa $5 \mathrm{mg} / \mathrm{kgbb}$ & $0.220 \pm 0.03$ \\
Xa10 mg/kgbb & $0.213 \pm 0.04$ \\
Xa20 mg/kgbb & $0.232 \pm 0.03$ \\
Glib $0,65 \mathrm{mg} / \mathrm{kgbb}$ & $0.278 \pm 0.04^{\mathrm{a}}$ \\
\hline
\end{tabular}

Note: AM: Alpha mangostin; Xa: Xanthone; Glib: Glibenclamide; a: anova test, insulin plasma mean different significantly $(p<0,05)$ when compared to control; samples were taken after 21 days treatment

\section{Effect on Langerhans Islet}

At the end of the 21-day treatment, histopathological assessment was carried out on pancreas mice (see Figure 1). Pancreas gland is composed of Langerhans islets that having function as pancreatic endocrine units. Langerhans Island has four kinds of cells, namely alpha, beta, delta and kappa cells. Beta cells produce insulin that important in glucose metabolism. Histopathologic changes in the pancreas can be caused by various factors, including genetic factors, infections, nutrients, diabetogenic substances and free radicals. 
Beta cells in the island of Langerhans (Islet of Langerhans) produce the hormone insulin that have role in regulating blood glucose levels. Insulin plays a role in glucose transport from the blood into the cells through insulin receptors on the surface of target cells. Insulin also affects the change of glucose into glycogen, reducing glycogenolysis and gluconeogenesis, stimulates changes in glucose or other nutrients into fatty acids (lipogenesis), and help to stimulate protein synthesis. ${ }^{5}$

Alloxan is a toxic diabetogenic substance, especially to pancreatic beta cells. The body will not produce insulin that needed in glucose metabolism caused by damaging pancreas. This results in a state of hyperglycemia. This condition will trigger the production of reactive oxygen species (ROS). Excessive ROS will aggravate the destruction of pancreatic beta cells Jung et al. says that alpha mangostin, gamma mangostin, gartanin, 8-hydroxyquadraxanthone and smeathxanthone have antioxidant activity. ${ }^{15}$ The destruction of the pancreatic beta cells can occur after one week to several months, even years, where a decline in the number of pancreatic beta cells, but the cells are not affected. ${ }^{12}$

The pancreas measured in this study were taken from the same experimental animal that had been measured for the fasting blood glucose and insulin above. In contrast to fasting blood glucose, effect on pancreatic beta cells was measured only at the end of the study. Histological preparations were made by the method of paraffin blocks with Gomori staining is presented in Figure 1.

In this study, we can saw that langerhans area in alloxan group were different to normal group. It means that alloxan destroy pancreatic betha cell that formed langerhans island, together with alpha cell. But infortunately in this study we can't observed it's effect directly to betha and alpha cell ratio. We only observe the difference of langerhans area. While if we compared the area between alpha mangostin and xanthone

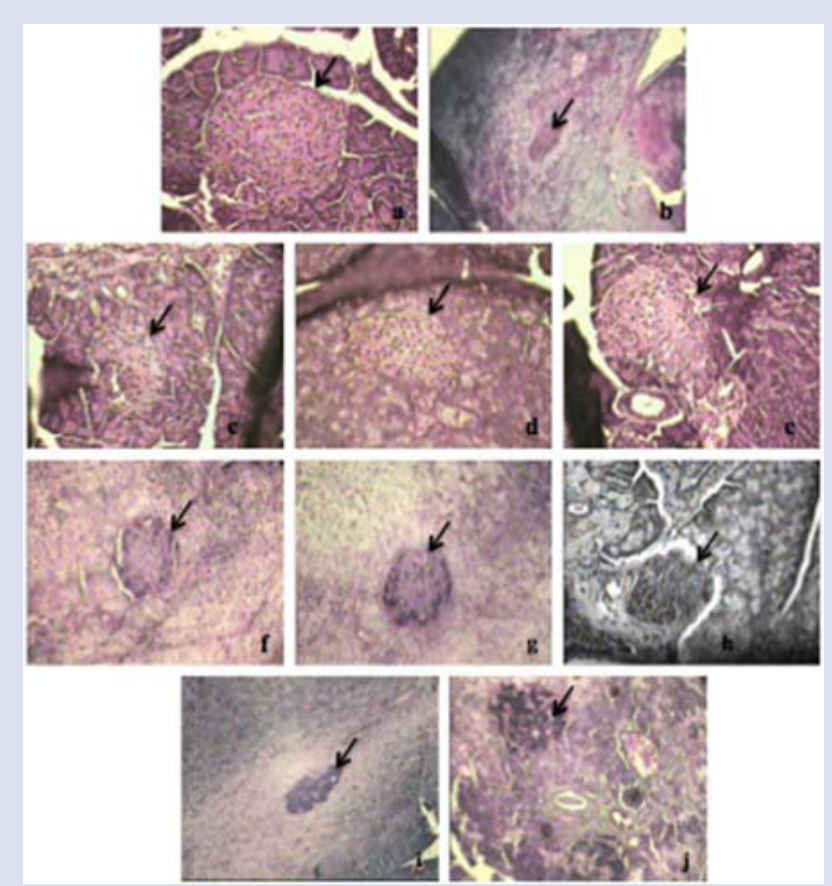

Figure 1: Histology of Langerhans islet after 21 days treatment on diabetic mice induced by alloxan. Note: a. normal; b control; c. alpha mangostin $5 \mathrm{mg} / \mathrm{kgbw}$; d. alpha mangostin $10 \mathrm{mg} / \mathrm{kgbw}$; e. alpha mangostin $20 \mathrm{mg} / \mathrm{kgbw}$; f. xanthone $5 \mathrm{mg} / \mathrm{kgbw}$; g. xanthone $10 \mathrm{mg} /$ kgbw; h. xanthone $20 \mathrm{mg} / \mathrm{kgbw}$; i. glibenklamid $0.65 \mathrm{mg} / \mathrm{kgbw}$; j. metformin $65 \mathrm{mg} / \mathrm{kgbw}$; samples were taken 21 days after treatment; magnification $400 x$ group to control, we will saw that alpha mangostin and xanthone improve the langerhans area. Glibenclamide and metformin group were not improved Langerhans regeneration, but it increase $\beta$-cells size and insulin secretion.

The microscopic analysis of pancreatic tissue obtained from the normal group showed the presence of a normal pancreatic tissue consist of the normal acini, normal cellular population, and absence of damaged islets or hyperplasia. Tissue from the diabetic control group demonstrated the presence of partial islets destruction with reduced size and observable flattening of nuclei, which were pushed to the periphery. The tissue obtained from glibenclamide-treated group revealed an obvious improvement with the recovery of normal pancreatic histoarchitecture.

Alloxan has two different effects: it selectively inhibits glucose-induced insulin secretion through specific inhibition of glucokinase and it causes a state of insulin-dependent diabetes through its ability to induce ROS formation, resulting in selective necrosis of beta cells. ${ }^{16}$ Necrotic and degenerative pancreas will be found in mice that induced by alloxan, exocrine cells of the pancreas were changed to fibrotic tissue. ${ }^{4}$

In this study, alloxan administration only caused shrunken in the islet of Langerhans. There was no evidence of degenerative and necrotic changes, and also no inflammatory cell infiltration. ${ }^{17}$ This study using $70 \mathrm{mg} / \mathrm{kgbw}$ dose of alloxan. Alpha mangostin showed a remarkable improvement in the islet of Langerhans in alloxan-induced diabetes. It might protected and preserved pancreatic $\beta$ cell integrity from oxidative stress. ${ }^{12,18-19}$ The present study highlighted the potential hypoglycemic action of alpha mangostin and xanthone in diabetic-induced mice. Increasing blood glucose level might be due to shortage of insulin as a result of Langerhans destruction interceded by alloxan action, which boosts ATP dephosphorylation, which in turn generates superoxide anions, hydrogen peroxide, and hydroxyl radicals. Elevated intracellular peroxides in pancreatic islets further mediate a damage induced by reactive oxygen species (ROS). ${ }^{7}$ Under hyperglycemic conditions, antioxidants are supposed to regenerate damaged extracellular matrix proteins and cell growth as a result of ROS elevation through non enzymatic glycation of proteins, as well as through auto-oxidation. ${ }^{8}$

This indication marks the increased levels of indicators of oxidative stress in diabetic patients. Because oxidative stress is associated with pathogenesis of diabetes, therefore, it can be postulated that the antioxidants may exert a key role in the management of DM. ${ }^{7}$ Provided the $\beta$-cells are fully functional, sulphonylureas such as glibenclamide can cause hypoglycemia because insulin release is initiated even when glucose concentrations are below the normal threshold for glucose-stimulated insulin release (approximately $5 \mathrm{mmol} / \mathrm{L}$ or $90 \mathrm{mg} / \mathrm{dL}$ ). ${ }^{2}$ Glibenclamide was used as a reference hypoglycemic agent to compare the efficacy of a variety of glucose-reducing compounds via enhanced activity of $\beta$-cells of the pancreas resulting in the secretion of larger amounts of insulin.

Histopathological examination revealed an improved preservation of normal pancreatic islets and diminished necrotic changes as compared to the alloxan induced diabetic mice. ${ }^{2,5-6}$ The effect of alpha mangostin might be due to the pancreatic rejuvenation via enhanced protein synthesis, accelerated detoxification, potentiation of antioxidant defense, and neutralization of free radicals, which confirmed the insulin tropic effect of alpha mangostin through the regeneration of insulin-producing $\beta$-cells.

Islet Langerhans cells in the group of diabetic mice visible reduction in the amount of cell mass, the size becomes smaller and some even disappeared. Islet Langerhans cells damage resulting in decreased insulin production that increases blood sugar levels. High blood sugar levels can exacerbate the destruction of islet Langerhans cells because it can increase the formation of ROS such as glucose metabolism through glu- 
cose auto-oxidation, oxidative phosphorylation, and increased oxidative stress in pancreatic beta cells. In the group of mice therapy where the islets of Langerhans shape, size and mass of the cell can still be maintained. This is presumably due to the influence of alpha mangostin and xanthone that able to neutralize free radicals that inhibit islet Langerhans cell damage. .-6, $^{414}$

The above results support the data measurement of fasting blood glucose levels in control group remains high, while mice receiving alpha mangostin and xanthone therapy was able to decrease a state of blood sugar levels significantly if we compare to control group. It was related to the state of islet Langerhans cells that undergo repairs. Although the overall pancreatic islet yet back to normal circumstances, but the improvement of pancreatic islet has been able to overcome the condition of hyperglycemia in animal models. This proves that alpha mangostin and xanthone has the potential effect as antidiabetic.

\section{CONCLUSION}

In conclusion, the present study has shown that $\alpha$-mangostin and xanthone isolated from mangosteen (G. mangostana L.) are two substance that showed potential effect on lowering fasting blood glucose, increasing insulin plasma and Langerhans islet area.

This work was supported by Jenderal Achmad Yani University and School of Pharmacy, Bandung Institute of Technology, Jawa Barat, Indonesia.

\section{CONFLICT OF INTEREST}

The authors declare no conflict of interests.

\section{ABBREVIATIONS}

DM: Diabetes mellitus; GLUT: Glucose transporter; ROS: Reactive oxygen species; Kgbw: Kilogram body weight.

\section{SUMMARY}

The effects of alpha mangostin and xanthone on fasting blood glucose were not significantly different from glibenclamide and metformin. Increasing alpha mangostin/xanthone dose from $5 \mathrm{mg} / \mathrm{kgbw}$ to $20 \mathrm{mg}$ / kgbw. did not cause significant differences, although the best results were obtained at a dose of $20 \mathrm{mg} / \mathrm{kgbw}$. Insulin plasma analize showed that there were no significant difference between alpha mangostin $20 \mathrm{mg} /$ kgbw to glibenclamide or normal group. Langerhans area showed significant difference between alpha mangostin/xanthone to control group.

\section{REFERENCES}

1. Duckworth WC. Hyperglycemia and cardiovascular disease. Curr Atheros Rep. 2001;3(5):383-91.

2. Krentz AJ, Bailey CJ. Oral antidiabetic agents: Current Role in Type 2 Diabetes Mellitus. Drug. 2005;65(3):385-411.

3. Kurniawati M, Mahdi C, Aulanni'am A. The effect of juice mangosteen Rind (Garcinia Mangostana L.) to Blood Sugar Levels and Histological of Pancreatic Rats with the Induction of Streptozotocin. J Pure App Chem Res. 2014;3(1):1-6.

4. Taher M, Syafiq TM, Zakaria T, Susanti D, Zakaria ZA. Hypoglycaemic activity of ethanolic extract of Garcinia mangostana Linn. In normoglycaemic and streptozotocin induced diabetic rats. BMC Complementary and Alternative Medicine. 2016;16(1):135.

5. Arisandi R. Anatomy and Physiology of Pancreas. Institut Pertanian Bogor. 2004

6. Defronzo RA, Ferrannini E, Keen H, Zimmetn DP. International Textbook of Diabetes Mellitus. 2004;2.

7. Lenzen S, Drinkgern J, Tiedge M. Low antioxidant enzyme gene expression in pancreatic islets compared with various other mouse tissues. Free Rad Biol Med. 1996;20(3):463-6.

8. Smith PR, Thornalley PJ. Mechanism of the degradation of non?enzymatically glycated proteins under physiological conditions. Eur J Biochem. 1992;210(3):729-39.

9. Peres V, Nagem TJ, De Oliveira FF. Tetraoxygenated naturally occurring xanthones. Phytochemistry. 2000;55(7):683-710.

10. Kondo M, Zhang L, Ji H, Kou Y, Ou B. Bioavailability and antioxidant effects of a xanthone-rich Mangosteen (Garcinia mangostana) product in humans. J Agric Food Chem. 2009;57(19):8788-92.

11. Mahabusarakam W, Wiriyachitra P, Taylor WC. Chemical constituents of Garcinia mangostana. J Nat Prod. 1987;50(3):474-8.

12. Clark A. Morphology of Pancreas in Normal and Diabetic States: International Text Book of Diabetes Mellitus. 2004.

13. Pedraza-Chaverri J, Cárdenas-Rodríguez N, Orozco-lbarra $M$, Pérez-Rojas JM Medicinal properties of mangosteen (Garcinia mangostana). Food Chem Toxicol. 2008;46(10):3227-39.

14. Lenzen S. The mechanism of alloxan and streptozotocin-induced diabetes. Diabetologia. 2008;51(2):216-26.

15. Jung HA, Su BN, Keller WJ, Mehta RG, Kinghorn AD. Antioxidant xanthones from the pericarp of Garcinia mangostana (mangosteen). J Agric Food Chem 2006;54(6):2077-82.

16. Chen LG, Yang LL, Wang CC. Anti-inflammatory activity of mangostins from Garcinia mangostana. Food Chem Toxicol. 2008;46(2):688-93.

17. Manaharan T, Palanisamy UD, Ming CH. Tropical plant extracts as potential antihyperglycemic agents. Molecules. 2012;17(5):5915-23.

18. Balasubramanian K, Rajagopalan K. Novel xanthones from Garcinia mangostana, structures of BR-xanthone-A and BR-xanthone-B. Phytochemistry. 1988;27(5):1552-4

19. Sen AK, Sarkar KK, Mazumder PC, Banerji N, Uusvuori R, Hase TA. The structures of garcinones $a, b$ and $c$ : Three new xanthones from Garcinia mangostana. Phytochemistry. 1982;21(7):1747-50. 